\title{
Next-generation Sequencing (NGS) Analysis on Single Circulating Tumor Cells (CTCs) with No Need of Whole-genome Amplification (WGA)
}

\author{
RAFFAELE PALMIROTTA, DOMENICA LOVERO, ERICA SILVESTRIS, CLAUDIA FELICI, \\ DAVIDE QUARESMINI, PAOLA CAFFORIO and FRANCO SILVESTRIS
}

Department of Biomedical Sciences and Human Oncology, University of Bari 'Aldo Moro', Bari, Italy

\begin{abstract}
Background: Isolation and genotyping of circulating tumor cells (CTCs) is gaining an increasing interest by clinical researchers in oncology not only for investigative purposes, but also for concrete application in clinical practice in terms of diagnosis, prognosis and decision treatment with targeted therapies. For the mutational analysis of single CTCs, the most advanced biotechnology methodology currently available includes the combination of whole genome amplification (WGA) followed by next-generation sequencing (NGS). However, the sequence of these molecular techniques is time-consuming and may also favor operator-dependent errors, related to the procedures themselves that, as in the case of the WGA technique, might affect downstream molecular analyses. Materials and Methods: A preliminary approach of molecular analysis by NGS on a model of CTCS without previous WGA procedural step was performed. We set-up an artificial sample obtained by spiking the SK-MEL-28 melanoma cell line in normal donor peripheral whole blood. Melanoma cells were first enriched using an AutoMACS ${ }^{\circledR}$ (Miltenyi) cell separator and then isolated as single and pooled CTCs by DEPArray ${ }^{T M}$ System (Silicon Biosystems). NGS analysis, using the Ion AmpliSeq ${ }^{T M}$ Cancer Hotspot Panel v2 (Life Technologies) with the Ion Torrent PGM ${ }^{T M}$ system (Life Technologies), was performed on the SK-MEL-28 cell pellet, a single CTC previously processed with WGA and on 1, 2, 4 and 8 recovered CTCs without WGA pre-amplification. Results:
\end{abstract}

This article is freely accessible online.

Correspondence to: Raffaele Palmirotta, Department of Biomedical Sciences and Human Oncology, University of Bari 'Aldo Moro', P.zza G. Cesare, 11 - 70124 Bari, Italy. E-mail: raffaelepalmirotta@ gmail.com

Key Words: Circulating tumor cells (CTCs), next generation sequencing (NGS), whole genome amplification (WGA), mutational analysis, targeted therapy.
NGS directly carried out on CTCs without WGA showed the same mutations identified in SK-MEL-28 cell line pellet, with a considerable efficiency and avoiding the errors induced by the WGA procedure. Conclusion: We identified a cost-effective, time-saving and reliable methodological approach that could improve the analytical accuracy of the liquid biopsy and appears promising in studying CTCs from cancer patients for both research and clinical purposes.

Accumulating clinical studies during the past few years suggest that circulating tumor cells (CTCs) exert a critical role in cancer dissemination, organ invasion and distant metastases (1). The biological process of transformation from a normal somatic cell to a cancer cell is characterized by a variable number of selective gene mutations specific for clonal evolution, diversity and metastatic capacity (2-4). Moreover, the presence of some specific sequence variants in driver genes is currently under intensive investigation for cancer molecular diagnosis and pharmacogenomics including prediction of either susceptibility or resistance to the targeted therapy (5-7). In this context, introduction of innovative biotechnologies allows to identify, recover and analyze CTCs from the peripheral blood to perform the so-called "liquid biopsy" procedure (8-16).

The method primarily used to obtain small amounts of DNA from a single cell as low as approximately $5 \mathrm{pg}$, is the wholegenome amplification (WGA), a molecular procedure that amplifies the cell DNA content $(17,18)$. However, based on the operator capability, this "pre-amplification" method can imply several technical errors and loss of data as insufficient coverage, allelic dropout, false-positives and false-negatives that definitely affect the analytical quality of the next generation sequencing (NGS) procedure (4, 17-20).

In this study, we investigated tqqhe feasibility of NGS directly performed on CTCs without the combination with previous WGA. For this purpose, to simulate a real blood sample from a cancer patient, we employed a model including a cancer cell line spiked in fresh healthy donor blood and utilized a hot spots targeted genes capture NGS commercial kit. 


\section{Materials and Methods}

Cell culture and spiking. The experimental design was performed using the SK-MEL-28 melanoma cell line. This commercial cell line was established from a patient-derived tumor sample (21) with identified mutations among which the best known is the BRAF p.V600E, as reported in COSMIC (http://cancer.sanger.ac.uk/ cell_lines) and CANSAR (https://cansar.icr.ac.uk/cansar/cell-lines/SKMEL-28/) databases (22). The adherent cells were cultured in RPMI 1640 medium supplemented with $10 \%$ fetal bovine serum (FBS Sigma-Aldrich, St. Louis, USA), $100 \mathrm{IU} / \mathrm{ml}$ penicillin/streptomycin and $2 \mathrm{mM}$ L-Glutamine (PAA, Paasching, Austria) in $5 \% \mathrm{CO}_{2^{-}}$ incubator. After detaching by trypsin-treatment, $1 \times 10^{3}$ SK-MEL-28 cells were spiked in $15 \mathrm{~mL}$ of normal donor peripheral whole blood in EDTA vacutainer tubes for subsequent CTCs isolation. A second aliquot of cultured cells was centrifuged, and the resulting cell pellet was submitted to DNA extraction by DNeasy Blood and Tissue kit (Qiagen, Germany) for direct NGS analysis (Figure 1).

Cell sorting. The spiked blood sample was processed by Ficoll (Sigma) gradient and depleted of $\mathrm{CD}^{4} 5^{+}$and Glycophorin ${ }^{+}$cells by immunomagnetic sorting procedure using an AutoMACS ${ }^{\circledR}$ (Miltenyi) cell separator. The negative selected cells were stained with anti-Melan-A phycoerythrin (PE) and anti-CD45 allophycocyanin (APC) (Miltenyi) conjugated antibodies, whereas nuclei were displayed with Hoechst 33342 after fixation and permeabilization. In particular, anti-CD45 antibody was used to exclude contaminating leucocytes.

Stained cells were resuspended in SB115 Buffer (Silicon Biosystems), a proprietary low-conductivity buffer for sorting fixed cells in the DEPArray ${ }^{\mathrm{TM}}$ cartridge, and the single cell sorting was performed by DEPArray ${ }^{\mathrm{TM}}$ System (Silicon Biosystems) according to the manufacturer's instruction. Briefly, cells were manually loaded into DEPArray ${ }^{\mathrm{TM}}$ cartridges (A300K) and injected by pump system into a microchamber where the cells were exposed to an electric field in which individual cells were trapped. Image frames for each fluorescent filter (PE, APC, and HOECHST 33342) and brightfield images were captured. Cell detection was based on HOECHST 33342 fluorescence threshold and images were processed by the CellBrowser software. Nucleated cells negative for CD45 and positive for Melan A were selected and moved to a parking area in the cartridge. Several single CTCs, namely one cell, and grouped cells (2, 4, 8 CTCs) were then shifted in the Exit Chamber, recovered with SB115 buffer into $200 \mu \mathrm{l}$ PCR tubes and processed for volume reduction in PBS. The samples were stored in $1 \mu \mathrm{l}$ of PBS at $-20^{\circ} \mathrm{C}$ until processed for subsequent steps.

NGS - Procedure number 1 . The DNA directly extracted from cell pellet using DNeasy ${ }^{\circledR}$ blood \& tissue Kit (Qiagen) was quantified with Qubit ${ }^{\circledR}$ fluorometer (Life Technologies ${ }^{\mathrm{TM}}$ Carlsbad, CA, USA). Ten ng of DNA extracted from the cell pellet were employed to prepare the barcoded library using the Ion AmpliSeq ${ }^{\mathrm{TM}}$ Library kit 2.0 and the Ion Xpress ${ }^{\mathrm{TM}}$ barcode adapters (Life Technologies), according to the manufacturer's instructions. The library was purified with Agent court AMPure XP (Beckman Coulter) and quantified with the Ion Library Quantitation Kit (Life Technologies) on the StepOne Plus system (Applied Biosystem). Template preparation was performed with the Ion OneTouch ${ }^{\mathrm{TM}} 2$ System and Ion One Touch ES. Finally, the sequencing was performed on PGM using Ion $\mathrm{PGM}^{\mathrm{TM}}$ Hi- $\mathrm{Q}^{\mathrm{TM}}$ Sequencing kit (Life Technologies) on

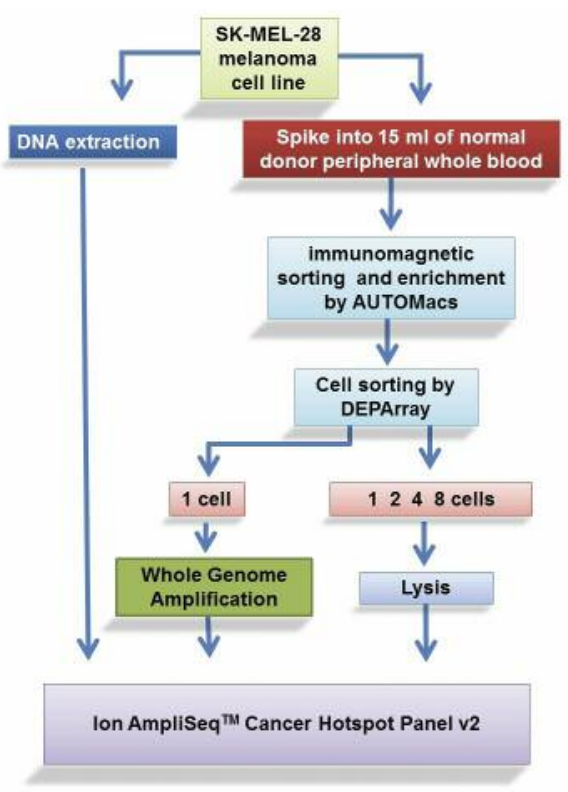

Figure 1. Schematic representation of the experimental design. An aliquot of SK-MEL-28 cells was subjected directly to extraction of DNA, while another aliquot was spiked into a peripheral blood aliquot on which was subsequently carried the tumor cell separation to resemble the liquid biopsy. A single cell recovered by the enrichment and purification was subjected to WGA. Other recovered single and pooled cells were subjected to cell lysis. Finally, next generation sequencing was performed on DNA extracted directly by SK-MEL-28 cell line pellets, on the WGA product of a single cell and on several individual and pool cells fitted directly into the working cycle of NGS without any DNA extraction or pre-amplification.

the Ion 314 chip v2 and set of 500 flows standard. The reaction sequence was carried out with a Ion Torrent PGM $^{\mathrm{TM}}$ system (Life Technologies) using a Ion AmpliSeq ${ }^{\mathrm{TM}}$ Cancer Hotspot Panel v2 (Life Technologies) kit that covers 270 amplicons of 50 oncogenes and anti-oncogenes including those mutated in the cell line used.

WGA and NGS - Procedure number 2. A single cell recovered by DEPArray $^{\mathrm{TM}}$ was processed using the Ampli1 ${ }^{\mathrm{TM}}$ WGA Kit (Silicon Biosystems) following the user guide instructions. The kit has been specifically developed for the amplification of total cellular DNA using a ligation-mediated PCR following a site-specific (5'T $\downarrow$ TAA3') MseI DNA digestion. Briefly, the reaction starts with a cell lysis and requires subsequent DNA digestion and pre-annealing, a ligation and a final primary PCR. Products quantification was performed using Qubit ${ }^{\circledR}$ fluorometer (Life Technologies). A quality control Ampli1 ${ }^{\mathrm{TM}}$ QC Kit (Silicon Biosystems), separated and visualized on $1,2 \%$ agarose gel, was used. For the NGS procedure, the same protocol carried out for cell pellet analysis was used with the exception of the adoption of set of an 850 flows.

$N G S$ - Procedure number 3. In order to identify a minimal number of cells for further sequencing, a single cell and cell suspensions including 2, 4 and 8 recovered cells were processed directly for downstream NGS analysis, thus avoiding the WGA procedures. Firstly, cell lysis with Ampli1 ${ }^{\mathrm{TM}}$ WGA Kit (Silicon Biosystems) was carried 


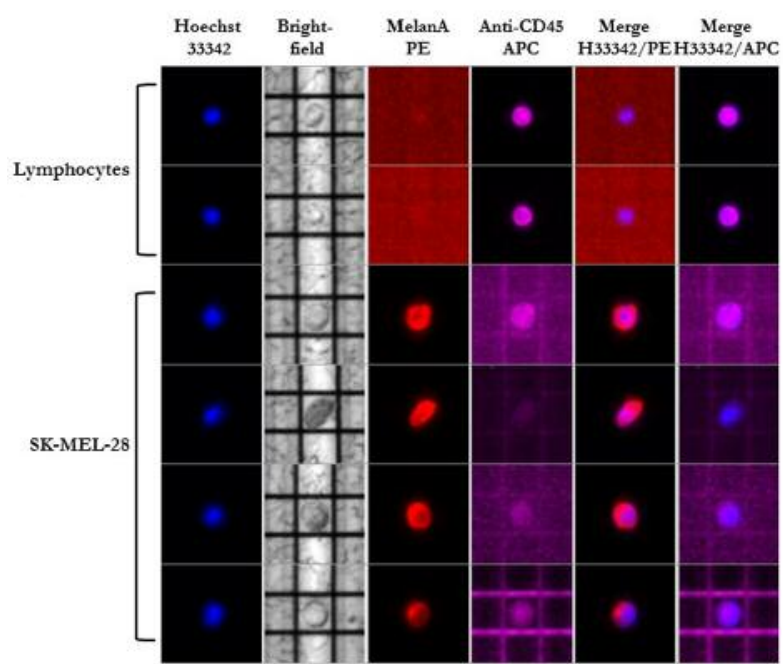

Figure 2. Representative panel showing four $S K-M E L-28$ cells and two leukocytes entrapped in DEPArray ${ }^{T M}$ cages. SK-MEL-28 cells were identified by MelanA expression (red) on nucleated cells (blue) and negativity for CD45 (purple), a specific marker of leukocytes. Conversely, leukocytes expressed CD45 and were negative for MelanA.

out according to the manufacturer's instructions. Then, barcoded libraries were obtained according to the Ion AmpliSeq ${ }^{\mathrm{TM}}$ DNA Library preparation user guide, with the only exception of an increase in the number of cycles during the "PCR amplify genomic DNA targets" (from 18 to 25 cycles) and the "Amplify the library" (from 5 to 8 cycles) steps (Ion AmpliSeq ${ }^{\mathrm{TM}}$ Library Preparation, Quick Reference, Publication Number MAN0006943 Revision 4.0). All the subsequent template preparations and sequencing reaction steps were performed following the same protocol carried out for WGA-treated cell analysis using the Ion 314 chip v2 and set for an 850 flows.

Data analysis. All samples were analyzed using the Torrent Suite Software 5.0.4 aligning all reads to the human reference hg19 Genome and variant calling was performed running the Torrent Variant Caller plugin version 5.0.4.0. Data were interpreted and verified using the visualization by IGV (Integrative Genomics Viewer) browser (Broad Institute). The calls obtained from CTCs subjected or not to WGA were compared to calls obtained from sequencing analysis performed on DNA directly extracted by cell pellet. In order to avoid false positives and to obtain an acceptable quality standard, the variants with a sequencing depth of at least $30 \mathrm{X}$ and an allelic frequency of at least $20 \%$ were considered. Each variant was investigated in its potential pathogenic role using both prediction algorithms such as SIFT, Polyphen, and WEB databases as COSMIC (http://cancer.sanger.ac.uk/cosmic) and dbSNP (https://www.ncbi.nlm.nih.gov/snp/).

\section{Results}

The enrichment by AutoMACS ${ }^{\circledR}$ system and the subsequent processing in DEPArray ${ }^{\mathrm{TM}}$ chip has allowed to identify 592 SK-MEL-28 cells with a recovery rate of $59.2 \%$. Thus, a

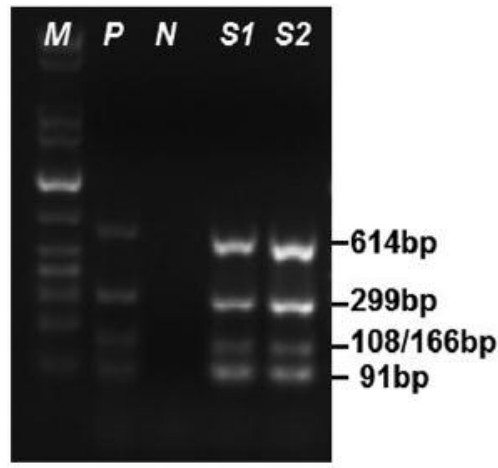

Figure 3. WGA quality control performed by Ampli1 ${ }^{T M}$ QC kit (Silicon Biosystems) amplification and $1.2 \%$ agarose gel electrophoresis. M: DNA molecular weight marker; P: positive control (human DNA); $N$ : negative control (water); S1 and S2: WGA output samples using Ampli1 ${ }^{T M}$ WGA kit (Silicon Biosystems).

series of 1 single and pools of 2, 4 and 8 SK-MEL-28 cells were sorted (Figure 2). The DEPAarray ${ }^{\mathrm{TM}}$ system ensured the recovery of viable pure homogenous tumor cells based on their peculiar expression of Melan A and negativity for leukocyte marker CD45.

NGS on unspiked cell pellet allowed the detection of 10 sequences variants in 9 genes. Of these variants, only three, BRAF p.V600E; EGFR p.P753S and PTEN p.T167A had already been reported in SK-MEL-28 cell line (https:// cansar.icr.ac.uk/cansar/cell-lines/SK-MEL-28/), while other 7 non pathogenic variants, including 5 synonymous and 2 intronic sequence variants, had never been reported before (Table I). Using the standard of 500 flows, an average reads per amplicon of 390 was achieved with the $100 \%$ and $96.14 \%$ of amplicon reads coverage at 20x and 100x respectively.

The WGA protocol on the single cell was carried out in 2 consecutive days and the quality control was verified before proceeding to sequencing. The control provided a good quality of DNA with the presence of 4 electrophoretic bands of 91, 108/166, 299 and $614 \mathrm{bp}$, representative of the chromosomes $12 p, 5 q, 17 p$ and $6 q$, respectively (23) (Figure 3). NGS performed on the WGA-treated cell identified the same variants detected in the cell pellet sample, with the exception of EGFR p.P753S and three of the novel identified non pathogenic variants FGFR3 p.T653T, HRAS p.H27H and STK11 c.465-51T>C (Table I). The restriction sites analysis of amplicons carrying these missed variants revealed the presence of two TTAA sites in the amplicon with the EGFR p.P753S mutation (CHP2_EGFR5), but not in the amplicons of the other variants. The loss of amplicons carrying the TTAA sequence was observed also in the extended analysis of all 207 amplicons, confirming the loss of data for many "hot spots", as previously reported in other studies (24). The sequencing, performed with an 850 flow set, led to an average 
Table I. Sequence variants identified by NGS in SK-MEL-28 pellet, single cell subjected to WGA, single cell, and pools of 2, 4 and 8 cells not subjected to WGA. For all samples, the number of average reads per amplicon, the amplicon reads coverage at 20x and 100x, has been reported. For each sequence variant the number of forward and reverse reads and the status in homozygosis (homo) or heterozygosis (het) are also reported.

\begin{tabular}{|c|c|c|c|c|c|c|c|c|c|}
\hline & & & & SK-ML-28 pellet & 1 cell WGA & 1 cell & 2 cells & 4 cells & 8 cells \\
\hline & \multicolumn{3}{|c|}{ Average reads per amplicon } & 390.9 & 732.1 & 704.2 & 822.9 & 521.7 & 733.9 \\
\hline & \multicolumn{3}{|c|}{ Amplicon reads coverage } & $20 x=100 \%$ & $20 x=74.40$ & $20 x=98.07$ & $20 x=98.55$ & $20 x=96.16$ & $20 x=92.75$ \\
\hline Gene & $\begin{array}{c}\text { Sequence } \\
\text { variant }\end{array}$ & $\begin{array}{l}\text { dBSNPs/ } \\
\text { COSMIC }\end{array}$ & $\begin{array}{l}\text { Already } \\
\text { reported }\end{array}$ & & & & & & \\
\hline$A P C$ & $\begin{array}{c}\text { c. } 4479 \mathrm{G}>\mathrm{A} ; \\
\text { p.T1493T }\end{array}$ & COSM3760869 & No & $\begin{array}{c}\text { homo } \\
(341 ; 307)\end{array}$ & $\begin{array}{l}\text { homo } \\
(61 ; 58)\end{array}$ & $\begin{array}{c}\text { homo } \\
(118 ; 143)\end{array}$ & $\begin{array}{c}\text { homo } \\
(155 ; 151)\end{array}$ & $\begin{array}{c}\text { homo } \\
(274 ; 269)\end{array}$ & $\begin{array}{l}\text { homo } \\
(54 ; 57)\end{array}$ \\
\hline$B R A F$ & $\begin{array}{l}\text { c. } 1799 \mathrm{~T}>\mathrm{A} \\
\text { p.V600E }\end{array}$ & COSM486 & Yes & $\begin{array}{c}\text { homo } \\
(203 ; 193)\end{array}$ & $\begin{array}{c}\text { homo } \\
(281 ; 324)\end{array}$ & $\begin{array}{c}\text { homo } \\
(128 ; 128)\end{array}$ & $\begin{array}{c}\text { homo } \\
(155 ; 121)\end{array}$ & $\begin{array}{c}\text { homo } \\
(138 ; 122)\end{array}$ & $\begin{array}{l}\text { homo } \\
(50 ; 34)\end{array}$ \\
\hline$E G F R$ & $\begin{array}{c}\text { c. } 2257 \mathrm{C}>\mathrm{T} \\
\text { p.P753S }\end{array}$ & COSM6268 & Yes & $\begin{array}{c}\text { homo } \\
(407 ; 230)\end{array}$ & - & $\begin{array}{c}\text { homo } \\
(108 ; 100)\end{array}$ & $\begin{array}{c}\text { homo } \\
(121 ; 130)\end{array}$ & $\begin{array}{c}\text { homo } \\
(327 ; 272)\end{array}$ & $\begin{array}{l}\text { homo } \\
(90 ; 77)\end{array}$ \\
\hline$E G F R$ & $\begin{array}{c}\text { c. } 2361 \mathrm{G}>\mathrm{A} \\
\text { p.Q787Q }\end{array}$ & rs 1050171 & No & $\begin{array}{c}\text { homo } \\
(109 ; 119)\end{array}$ & $\begin{array}{c}\text { homo } \\
(139 ; 164)\end{array}$ & $\begin{array}{l}\text { homo } \\
(22 ; 22)\end{array}$ & $\begin{array}{l}\text { homo } \\
(20 ; 17)\end{array}$ & $\begin{array}{l}\text { homo } \\
(9 ; 16)\end{array}$ & $\begin{array}{c}\text { homo } \\
20 ; 9\end{array}$ \\
\hline FGFR3 & $\begin{array}{c}\text { c. } 1959 \mathrm{G}>\mathrm{A} \\
\text { p.T653T }\end{array}$ & rs7688609 & No & $\begin{array}{l}\text { homo } \\
(76 ; 70)\end{array}$ & - & $\begin{array}{c}\text { homo } \\
(157 ; 159)\end{array}$ & $\begin{array}{c}\text { homo } \\
(206 ; 178)\end{array}$ & $\begin{array}{c}\text { homo } \\
(123 ; 149)\end{array}$ & $\begin{array}{c}\text { homo } \\
(473 ; 396)\end{array}$ \\
\hline FLT3 & c. $1310-3 \mathrm{~A}>\mathrm{G}$ & rs 2491231 & No & $\begin{array}{c}\text { het } \\
(148 ; 198)\end{array}$ & $\begin{array}{c}\text { het } \\
(691 ; 912)\end{array}$ & $\begin{array}{c}\text { het } \\
(1078 ; 1184)\end{array}$ & $\begin{array}{c}\text { het } \\
(1336 ; 1401)\end{array}$ & $\begin{array}{c}\text { het } \\
(518 ; 655)\end{array}$ & $\begin{array}{c}\text { het } \\
(900 ; 959)\end{array}$ \\
\hline HRAS & $\begin{array}{l}\text { c. } 81 \mathrm{~T}>\mathrm{C} \\
\text { p.H27H }\end{array}$ & COSM249860 & No & $\begin{array}{c}\text { het } \\
(103 ; 63)\end{array}$ & - & $\begin{array}{c}\text { het } \\
(414 ; 349)\end{array}$ & $\begin{array}{c}\text { het } \\
(438 ; 441)\end{array}$ & $\begin{array}{l}\text { het } \\
(73 ; 62)\end{array}$ & $\begin{array}{c}\text { het } \\
(644 ; 614)\end{array}$ \\
\hline PDGFRA & $\begin{array}{c}\text { c. } 1701 \mathrm{~A}>\mathrm{G} \\
\text { p. } \mathrm{P} 567 \mathrm{P}\end{array}$ & rs 1873778 & No & $\begin{array}{c}\text { homo } \\
(137 ; 114)\end{array}$ & $\begin{array}{c}\text { homo } \\
(514 ; 344)\end{array}$ & $\begin{array}{c}\text { homo } \\
(100 ; 103)\end{array}$ & $\begin{array}{c}\text { homo } \\
(115 ; 123)\end{array}$ & $\begin{array}{l}\text { homo } \\
(142 ; 97)\end{array}$ & $\begin{array}{c}\text { homo } \\
(28 ; 28)\end{array}$ \\
\hline PTEN & $\begin{array}{l}\text { c. } 499 \mathrm{~A}>\mathrm{G} \\
\text { p.T167A }\end{array}$ & COSM5052 & Yes & $\begin{array}{c}\text { homo } \\
(145 ; 175)\end{array}$ & $\begin{array}{l}\text { homo } \\
(50 ; 77)\end{array}$ & $\begin{array}{c}\text { homo } \\
(59 ; 70)\end{array}$ & $\begin{array}{c}\text { homo } \\
(72 ; 93)\end{array}$ & $\begin{array}{c}\text { homo } \\
(87 ; 120)\end{array}$ & $\begin{array}{l}\text { homo } \\
(5 ; 10)\end{array}$ \\
\hline STK11 & c. $465-51 \mathrm{~T}>\mathrm{C}$ & rs2075606 & No & $\begin{array}{l}\text { het } \\
(92 ; 76)\end{array}$ & - & $\begin{array}{l}\text { het } \\
(88 ; 74)\end{array}$ & $\begin{array}{c}\text { het } \\
(85 ; 92)\end{array}$ & $\begin{array}{c}\text { het } \\
(87 ; 81)\end{array}$ & $\begin{array}{l}\text { het } \\
(18 ; 13)\end{array}$ \\
\hline
\end{tabular}

reads per amplicon of 732 and an amplicon reads coverage at $20 \times$ and $100 \times$ of $74.40 \%$ and $60.87 \%$ respectively (Table I).

NGS directly carried out on 1 single cell and the pools of 2 , 4 and 8 cells avoiding WGA showed the same mutations identified in SK-MEL-28 cell line pellet (including the four notcalled variants of the WGA-treated cell) (Table I). The 92-98\% and $72-91 \%$ of the amplicons exceeded coverage of $20 \times$ and $100 \times$ with a mean average reads per amplicon of 695 (Table I).

\section{Discussion}

In the present study, we describe a preliminary approach of molecular analysis by NGS on a model of single CTCs without WGA pre-treatment. This methodological procedure appears suitable for identifying mutations of driver genes, may be applied in clinical investigation of CTCs and, to our knowledge, has never been reported before.

Several systems for pre-amplification of total DNA template have been developed to overcome the insufficiency in the amount of DNA recovered from a single cell for successive molecular analyses. Major chemistries employed in the single- cell WGA include the degenerate oligonucleotide-primed polymerase chain reaction (DOP-PCR), the multiple displacement amplification (MDA), the multiple annealing and looping-based amplification cycles (mALBAC) and the ligationmediated PCR following a site specific DNA digestion as in the case of this study $(4,17,19,20,25-27)$. However, besides the operator capability, all these strategies are labor-intensive, require long time of execution and may imply different degrees of errors due to inappropriate starting in the early stages of amplification, or due to the specific chemicals used in the reaction $(17,18,28)$.

The WGA Ampli1 ${ }^{\mathrm{TM}}$ system enables excellent qualitative and quantitative performance and is one of the preferred methods, due to its higher yield for CTCs isolated by the DEPArray $^{\mathrm{TM}}$ cell separator according to our previous experience and recent data from the literature $(12,23,24)$. This technique is based on the DNA cleavage of the TTAA MseI restriction-site motifs (http://www.siliconbiosystems.com/feefor-service) and, in addition to potential drawbacks mentioned above, there is the inconvenient of failure to generate amplicons suitable for subsequent sequencing in case of DNA tracts carrying this motif $(19,24,29)$. For this reason, we 
planned an experimental design carried out to avoid WGA step in NGS protocol for CTCs. Our initial approach and preliminary results deserve some considerations.

Using conventional NGS analysis on SK-MEL-28 cell pellet, we revealed three variants reported in the COSMIC cell line database and other seven variants that had never been previously reported. As expected, and previously described, in CTCs subjected to the WGA procedure, the presence of the MseI restriction site in one amplicon did not allow the identification of the EGFR p.P753S mutation (24). Furthermore, by extending the analysis to all 207 amplicons of the panel covering 50 oncogenes and tumor suppressor genes, we confirmed the absence of amplification in regions carrying the restriction site. In some cases the loss of amplification involved several amplicons, while in other cases, such as for JAK2 and NPM1, all gene sequences were missing (24). In particular, as previously described by Salvianti et al., 17 genes (34\%) were partially and 2 genes (8\%) were totally not amplified (24). Examining the 2,855 hot spots, covered by the 207 amplicon, we identified 416 mutations $(14.6 \%)$ potentially not amplifiable for the presence of a MseI restriction site. In the WGA-treated cell, no restriction sites were found in the other three undetected variants. The reason for these missing amplifications as observed in other studies, may be related to the procedural difficulties in the use of the kit, or to the WGA procedure itself (29-31). Conversely, using our methodological approach, in WGA-untreated CTCs we identified the same 10 variants as in the SK-MEL-28 pellet. With a set of 850 flows in these samples we found a coverage more than adequate to call heterozygous variants as in the case of FLT3 c.1310-3A>G, HRAS p.H27H and STK11 c.465$51 \mathrm{~T}>\mathrm{C}(4,32)$. Only in few cases we found a relative low number of reads of the mutated nucleotide, especially in the case of amplicons carrying the EGFR p.Q787Q variant (Table I).

In our intent to determine an ideal minimal number of CTCs suitable to be analyzed without WGA, we could not identify a potential numerical threshold. The limiting factor for the appropriateness of the technique seems to be the quality of the DNA sample itself, rather than the number of initial DNA copies, since the number of cells did not influence the library construction and sequencing. However, it is also possible that a higher number of cells releasing cellular components during the lysis, induce a slight inhibition of the amplification reactions.

We completed preliminary studies using the same experimental design with a standard 500 flows set in sequencing procedures. Although promising, the depth coverage from our results did not fully satisfy the criteria for the acceptability of sequencing results (data not shown). Hence, we performed a new series of sequencing with an increase flow of 850 and detected a significant increase rate in coverage. This observation suggests to use other analytical variants, raising coverage until to $3000 \times$ in order to overcome troubles such as the reported low efficiency $(24,32,33)$.
As described in other studies, we did not find any degree of mutational heterogeneity in our model of CTC investigation, but this might be due to the use of a stabilized cell line and to the relatively low number of samples $(24,32)$. Thus, in our study we approached an efficient method to avoid the use of WGA on CTCs prior to mutational analysis by NGS, with the undoubted advantage to spare 2 working days in the time required for the analysis by one highly qualified operator. However, several limitations can be identified in our study conducted on a restricted number of samples. First, we have tested the possibility of a direct sequencing of CTCs but among the numerous analytical variants we have considered only the number of PCR cycles and cell pools. It will be also essential to evaluate other commercial and custom sequencing kits to evaluate the broad- as well as the depth-coverage of the reactions $(34,35)$. Further studies are mandatory to implement the efficiency of the method and to evaluate the use of the appropriate technical solutions such as the use of more powerful chips and adequate runs, the utilization of specific analysis workflows, or the evaluation of different blood collection tubes (23). Finally, despite the reduction of lead times and the reduction of potential pre-amplification mistake, we must take into account potential errors due to the increase of the amplification cycles during the construction of libraries.

Given its wide margins of improvement, this approach is promising not only for research purposes, but also for clinical application. CTCs have been associated to cancer diagnosis, prognosis and are especially useful for personalized treatments with targeted therapies (10, 36-38).

Several sensitivity and resistance mutations to tailored therapies have been described in most cases, and repeatable and routinely analysis of selected mutational hot spots, like sensibility or resistance mutations in cancers, would reduce both human and economic resources and the time required to obtain promptly therapeutically-applicable data $(4,6,7)$.

In conclusion, we hope that further studies on this topic will quickly lead to a real advantage in the study of CTCs, making this technique an efficient monitoring route for cancer patients.

\section{Conflicts of Interest}

The Authors have no other relevant affiliations or financial involvement with any organization or entity with a financial interest in or financial conflict with the subject matter or materials discussed in the manuscript apart from those disclosed.

\section{Acknowledgements}

This work was partially supported by a grant from the Italian Association for Cancer Research (AIRC, IG17536) (Franco Silvestris) and from the Apulia Region ("Oncogenomic Project"). The authors also thank A. R. B. Onlus (Associazione per la Ricerca Biomolecolare Onlus) for supporting the publication of this paper. 


\section{References}

1 Zhang X, Marjani SL, Hu Z, Weissman SM, Pan X and Wu S: Single-cell sequencing for precise cancer research: Progress and prospects. Cancer Res 76(6): 1305-1312, 2016.

2 Izumchenko E, Chang X, Brait M, Fertig E, Kagohara LT, Bedi A, Marchionni L, Agrawal N, Ravi R, Jones S, Hoque MO, Westra WH and Sidransky D: Targeted sequencing reveals clonal genetic changes in the progression of early lung neoplasms and paired circulating DNA. Nat Commun 6: 8258, 2015.

3 Trape AP and Gonzalez-Angulo AM: Breast cancer and metastasis: On the way toward individualized therapy. Cancer Genomics Proteomics 9(5): 297-310, 2012.

4 Navin NE: Cancer genomics: One cell at a time. Genome Biol 15(8): 452, 2014

5 Palmirotta R, Ludovici G, De Marchis ML, Leone B, Formica V, Ettorre GM, Cavaliere F, Della-Morte D, Ferroni P, Roselli $\mathrm{M}$ and Guadagni F: A comprehensive procedural approach to genotyping kras and braf from paraffin embedded tissues for diagnostic purposes. In Vivo 26(4): 537-547, 2012.

6 Savonarola A, Palmirotta R, Guadagni F and Silvestris F: Pharmacogenetics and pharmacogenomics: Role of mutational analysis in anti-cancer targeted therapy. Pharmacogenomics J 12(4): 277-286, 2012.

7 Palmirotta R, De Marchis ML, Ludovici G, Leone B, Covello R, Conti S, Costarelli L, Della-Morte D, Ferroni P, Roselli M and Guadagni F: Mutational analysis of gastrointestinal stromal tumors (gists): Procedural approach for diagnostic purposes. Cancer Genomics Proteomics 10(3): 115-123, 2013.

8 Bogani G, Liu MC, Dowdy SC, Cliby WA, Kerr SE, Kalli KR, Kipp BR, Halling KC, Campion MB and Mariani A: Detection of circulating tumor cells in high-risk endometrial cancer. Anticancer Res 35(2): 683-687, 2015.

9 Chudasama D, Barr J, Beeson J, Beddows E, McGonigle N, Rice A, Nicholson A and Anikin V: Detection of circulating tumour cells and survival of patients with non-small cell lung cancer. Anticancer Res 37(1): 169-173, 2017.

10 Strauss WM, Carter C, Simmons J, Klem E, Goodman N, Vahidi B, Romero J, Masterman-Smith M, O'Regan R, Gogineni K, Schwartzberg L, Austin LK, Dempsey PW and Cristofanilli M: Analysis of tumor template from multiple compartments in a blood sample provides complementary access to peripheral tumor biomarkers. Oncotarget 7(18): 26724-26738, 2016.

11 Weaver WM, Tseng P, Kunze A, Masaeli M, Chung AJ, Dudani JS, Kittur H, Kulkarni RP and Di Carlo D: Advances in highthroughput single-cell microtechnologies. Curr Opin Biotechnol 25: 114-123, 2014.

12 Babayan A, Alawi M, Gormley M, Muller V, Wikman H, McMullin RP, Smirnov DA, Li W, Geffken M, Pantel K and Joosse SA: Comparative study of whole genome amplification and next generation sequencing performance of single cancer cells. Oncotarget, 2016. doi: 10.18632/oncotarget.10701. [Epub ahead of print]

13 Hart CD, Galardi F, Pestrin M, De Luca F, Risi E and Di Leo A: Using ctcs for pharmacogenomic analysis. Pharmacological Research 106: 92-100, 2016.

14 Navin NE: The first five years of single-cell cancer genomics and beyond. Genome Res 25(10): 1499-1507, 2015.
15 Thalgott M, Rack B, Horn T, Heck MM, Eiber M, Kubler H, Retz M, Gschwend JE, Andergassen $U$ and Nawroth R: Detection of circulating tumor cells in locally advanced highrisk prostate cancer during neoadjuvant chemotherapy and radical prostatectomy. Anticancer Res 35(10): 5679-5685, 2015.

16 Pantel K and Alix-Panabieres C: Liquid biopsy: Potential and challenges. Mol Oncol 10(3): 371-373, 2016.

17 Huang L, Ma F, Chapman A, Lu S and Xie XS: Single-cell whole-genome amplification and sequencing: Methodology and applications. Annu Rev Genomics Hum Genet 16: 79-102, 2015.

18 Stranska J, Jancik S, Slavkovsky R, Holinkova V, Rabcanova M, Vojta P, Hajduch M and Drabek J: Whole genome amplification induced bias in the detection of kras-mutated cell populations during colorectal carcinoma tissue testing. Electrophoresis $36(6)$ : 937-940, 2015.

19 Gasch C, Pantel K and Riethdorf S: Whole genome amplification in genomic analysis of single circulating tumor cells. Methods Mol Biol 1347: 221-232, 2015.

20 Normand E, Qdaisat S, Bi W, Shaw C, Van den Veyver I, Beaudet A and Breman A: Comparison of three whole genome amplification methods for detection of genomic aberrations in single cells. Prenat Diagn 36(9): 823-830, 2016.

21 Carey TE, Takahashi T, Resnick LA, Oettgen HF and Old LJ: Cell surface antigens of human malignant melanoma: Mixed hemadsorption assays for humoral immunity to cultured autologous melanoma cells. Proc Natl Acad Sci USA 73(9): 3278-3282, 1976.

22 Reid AL, Freeman JB, Millward M, Ziman M and Gray ES: Detection of braf-v600e and v600k in melanoma circulating tumour cells by droplet digital pcr. Clin Biochem 48(15): 9991002, 2015.

23 Yee SS, Lieberman DB, Blanchard T, Rader J, Zhao J, Troxel AB, DeSloover D, Fox AJ, Daber RD, Kakrecha B, Sukhadia S, Belka GK, DeMichele AM, Chodosh LA, Morrissette JJ and Carpenter EL: A novel approach for next-generation sequencing of circulating tumor cells. Mol Genet Genomic Med 4(4): 395-406, 2016.

24 Salvianti F, Rotunno G, Galardi F, De Luca F, Pestrin M, Vannucchi AM, Di Leo A, Pazzagli M and Pinzani P: Feasibility of a workflow for the molecular characterization of single cells by next generation sequencing. Biomol Detect Quantif 5: 23-29, 2015.

25 Sabina $\mathrm{J}$ and Leamon JH: Bias in whole genome amplification: Causes and considerations. Methods Mol Biol 1347: 15-41, 2015.

26 Hou Y, Wu K, Shi X, Li F, Song L, Wu H, Dean M, Li G, Tsang S, Jiang R, Zhang X, Li B, Liu G, Bedekar N, Lu N, Xie G, Liang H, Chang L, Wang T, Chen J, Li Y, Zhang X, Yang H, Xu $\mathrm{X}$, Wang $\mathrm{L}$ and Wang $\mathrm{J}$ : Comparison of variations detection between whole-genome amplification methods used in singlecell resequencing. Gigascience 4: 37, 2015.

27 Yilmaz S and Singh AK: Single cell genome sequencing. Curr Opin Biotechnol 23(3): 437-443, 2012.

28 Zhu W, Zhang XY, Marjani SL, Zhang J, Zhang W, Wu S and Pan $X$ : Next-generation molecular diagnosis: Single-cell sequencing from bench to bedside. Cell Mol Life Sci 74(5): 869-880, 2017.

29 Polzer B, Medoro G, Pasch S, Fontana F, Zorzino L, Pestka A, Andergassen U, Meier-Stiegen F, Czyz ZT, Alberter B, Treitschke S, Schamberger T, Sergio M, Bregola G, Doffini A, Gianni S, Calanca A, Signorini G, Bolognesi C, Hartmann A, Fasching PA, Sandri MT, Rack B, Fehm T, Giorgini G, Manaresi N and Klein CA: Molecular profiling of single circulating tumor cells with diagnostic intention. EMBO Mol Med 6(11): 1371-1386, 2014. 
30 Zheng YM, Wang N, Li L and Jin F: Whole genome amplification in preimplantation genetic diagnosis. J Zhejiang Univ Sci B 12(1): 1-11, 2011.

31 Maciejewska A, Jakubowska J and Pawlowski R: Different whole-genome amplification methods as a preamplification tool in $\mathrm{y}$-chromosome loci analysis. Am J Forensic Med Pathol 35(2): 140-144, 2014.

32 Neumann MH, Schneck H, Decker Y, Schomer S, Franken A, Endris V, Pfarr N, Weichert W, Niederacher D, Fehm T and Neubauer $\mathrm{H}$ : Isolation and characterization of circulating tumor cells using a novel workflow combining the cellsearch(r) system and the cellcelector. Biotechnol Prog 33(1): 125-132, 2016.

33 Fernandez-Cuesta L, Perdomo S, Avogbe PH, Leblay N, Delhomme TM, Gaborieau V, Abedi-Ardekani B, Chanudet E, Olivier M, Zaridze D, Mukeria A, Vilensky M, Holcatova I, Polesel J, Simonato L, Canova C, Lagiou P, Brambilla C, Brambilla E, Byrnes G, Scelo G, Le Calvez-Kelm F, Foll M, McKay JD and Brennan P: Identification of circulating tumor DNA for the early detection of small-cell lung cancer. EBioMedicine 10: 117-123, 2016.

34 Millat G, Chanavat V and Rousson R: Evaluation of a new ngs method based on a custom ampliseq library and ion torrent pgm sequencing for the fast detection of genetic variations in cardiomyopathies. Clin Chim Acta 433: 266-271, 2014.
35 Buermans HP and den Dunnen JT: Next generation sequencing technology: Advances and applications. Biochim Biophys Acta 1842(10): 1932-1941, 2014.

36 Lyberopoulou A, Galanopoulos M, Aravantinos G, Theodoropoulos GE, Marinos E, Efstathopoulos EP and Gazouli M: Identification of methylation profiles of cancer-related genes in circulating tumor cells population. Anticancer Res 37(3): 1105-1112, 2017.

37 Mego M, Gao H, Cohen EN, Anfossi S, Giordano A, Sanda T, Fouad TM, De Giorgi U, Giuliano M, Woodward WA, Alvarez RH, Valero V, Ueno NT, Hortobagyi GN, Cristofanilli M and Reuben JM: Circulating tumor cells (ctc) are associated with defects in adaptive immunity in patients with inflammatory breast cancer. J Cancer 7(9): 1095-1104, 2016.

38 Usiakova Z, Mikulova V, Pinterova D, Brychta M, Valchar J, Kubecova M, Tesarova P, Bobek V and Kolostova K: Circulating tumor cells in patients with breast cancer: Monitoring chemotherapy success. In Vivo 28(4): 605-614, 2014.

Received February 10, 2017

Revised April 4, 2017

Accepted April 5, 2017 